When I asked a researcher working for the European Border and Coast Guard Agency (then known as Frontex) about its European Border Surveillance System (EUROSUR), he described its aim as "coordination, training and funding”. Technology wasn't mentioned.

The aim of such monitoring is to create 'situational awareness'. . Originally a military term, situational awareness involves visualizing critical situations, such as irregular border crossings or emergencies, to assess whether interventions are required. In addition to boats, cameras and radar, EUROSUR has used satellite imagery since 2014, obtained through the European Union Satellite Centre.

For example, when the Hellenic Coast Guard spots an unregistered ship in Greek waters, it contacts the national coordination centre in Piraeus. The centre asks the European Border and Coast Guard Agency in Warsaw to compare the crew's observation with satellite images. On the basis of that combined information, the Hellenic Coast Guard decides what to do.

Monitoring is usually done on the cheap. Variability and inadequate interventions are the result. For example, during field work in the Aegean islands, I saw how migration management is often improvised. Fingerprinting machines were in short supply and coastguards had to bring their own laptops to receive shipping information.

Overemphasis on technology also complicates rather than simplifies border controls because many professions are involved and responsibilities are fragmented. Government departments and policies on labour, health, security, humanitarian efforts and development mingle. Many borders are militarized, for instance by NATO operations, or are patrolled by security guards from private firms. Customs officers and police are increasingly supported by data analysts, software developers and IT managers, as well as by medical professionals.

Sometimes the simplest tools work best. Migrants trying to reach European countries by sea from Turkey and Libya are often rescued after calling for help on a mobile phone, or after being spotted by a patrol ship - not because they've been identified on integrated satellite images from EUROSUR.

\section{BORDER ENCOUNTERS}

Identification, authentication and registration increasingly rely on information derived from our bodies - fingerprints, DNA and iris scans. These processes may invade people's privacy and affect how they view their bodies. Such interventions place high demands on the integrity of professionals and companies. Over-restrictive interpretations of the tests result in questionable rejections or passes.

We are seeing 'dragnet policies' in which large amounts of biophysical data are

collected for undefined future purposes. The European Dactyloscopy fingerprintidentification system (EURODAC) was intended to prevent individuals making multiple asylum applications and to stop unauthorized entry. Access was extended later to police and public prosecutors and Europol ${ }^{2}$. There are no guarantees that its function will not be extended further.

Speech-recognition technology is applied in the Netherlands when testing the language proficiency of people acquiring a residence permit. But experts disagree on whether such software is accurate enough for this purpose. In Sweden and Cyprus, asylum seekers can voluntarily have X-rays taken to show whether they are children or adults, but that distinction is subjective even among medical professionals. DNA tests of family relationships reduce ties to biological kin

"Technology does not capture the reasons why people migrate." and may exclude

distant relatives or children who are not biologically related to a parent.

Technologies also affect the discretionary decision-making powers of civil servants ${ }^{3}$. When a person applies for asylum, examiners have to probe their flight stories using detailed regional maps and automated decision trees, for example, to check the country of origin. Because assumptions are made when applying these tools, technologies cannot be disentangled from the decisions that they enable.

Technology is viewed by many immigration services as more accurate than interviews in authenticating people's accounts. But it is limited in use and prone to errors, especially when systems are not harmonized and poor-quality data are collected. It does not capture the reasons why people migrate. Such information is valuable to governments when setting asylum policies, for example, because it allows them to determine which countries can be considered safe and which are dangerous.

\section{NON-STATE SURVEILLANCE}

With state monitoring a mess, non-state agencies are applying their own technologies. Migrant organizations use electronic devices to connect to online mapping platforms. In Europe, these include Watch the Med (www. watchthemed.net) and the Alarm Phone (https://alarmphone.org/en), which aim to monitor deaths and violations of migrants' rights at the maritime borders of the EU.

To visualize dramatic events or to gather

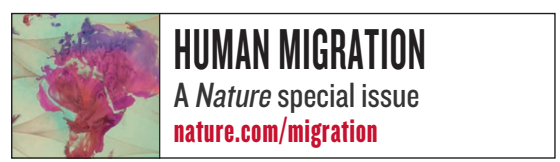

evidence, some non-governmental organizations run their own satellites. For example, in 2010, actor George Clooney and rights activist John Prendergast started the Satellite Sentinel Project (www.satsentinel.org; now no longer operating) to document violent attacks, human displacement and mass graves in Sudan. Despite good intentions and lots of media coverage, such projects have been criticized for offering no more information than was already available from other sources, such as the testimonies of survivors ${ }^{4}$.

Such 'border theatre' fuels controversies and increases the risk of fraud and corruption. Mobility becomes a security issue, with a constant stream of crises and emergencies.

Scandals erupt when governments fail to follow the law or use violence. For example, in January 2014 a boat carrying 28 passengers that had entered Greek waters from Turkey capsized close to the island of Farmakonisi. According to the survivors, it was being towed back to Turkey by a Greek coastguard vessel. Greek authorities said it was being taken to the island. Eleven people from Afghanistan, including eight children, drowned. Activists and relatives of the victims demanded an investigation. The Greek authorities refused, considering the testimonies unfounded.

Information on the precise positions of the boats has not been forthcoming, even though coordinates are normally registered through coastal positioning systems and radar. The Greek authorities released handwritten logs and said that the coastguard ship's video cameras had been switched off. On behalf of the survivors, a team of Greek lawyers filed a complaint with the European Court of Human Rights. So far, there has been no trial and the court's decision is pending.

Activists and legal advisers to migrants therefore urge people at sea to use mobile phones and other devices to track their whereabouts during crossings as proof of their experiences.

Non-governmental organizations and university departments are studying how monitoring technologies and big-data analysis can be used to support ethical and legal frameworks. In its Science for Human Rights project with the American Association for the Advancement of Science, Amnesty International is spurring the development of new geospatial tools, such as satellite imagery for human-rights monitoring (go.nature. com/2lehsxr). The Eyewitness to Atrocities project, developed by the International Bar Association, lets people document humanrights violations by taking photos and recording videos with their smartphones (www.eyewitnessproject.org).

Such 'counter-surveillance' can be used by migrants to post information on databases about violations while they are travelling or waiting at borders, to hold states accountable and raise public awareness. 
Examples include the border-crossing observatory in Australia, the Arizona OpenGIS Initiative for Deceased Migrants (http://humaneborders.info) and, in Europe, the Migrants' Files (www. themigrantsfiles.com), Watch the Med and the Deaths at the Borders Database (www.borderdeaths.org).

\section{NEXT STEPS}

When introducing new technologies, from drones to databases, governments rarely ask whether the tools will improve on current systems, or at what price. Proportionality and effectiveness ought to be criteria in every major decision, together with solid ethical principles such as purpose limitation and non-discrimination.

Scientists who help to develop monitoring technologies should work more closely with researchers who are specialists in law and the social consequences of technologies. This will further the development of regulatory and ethical frameworks.

Collaborations of scientists and research consortia with non-governmental organizations and the UN should encourage the development of instruments to monitor humanitarian dramas, as well as of devices and apps that migrants themselves can use in emergencies.

Providing decision-makers and the public with an accurate overview of technology's role in managing international human mobility is crucial for establishing solid migration policies.

Because migration is increasingly bound up with questions of security, technological developments should be treated with discretion. Moving border controls and the management of migration to other countries places the consequences of this externalization out of sight of citizens. Researchers who study the application of technologies and their consequences should collaborate with journalists to point out the gaps in the policy patchwork.

Huub Dijstelbloem is a senior researcher at the Netherlands Scientific Council for Government Policy in The Hague, and professor of philosophy of science and politics at the University of Amsterdam, the Netherlands.

e-mail:h.o.dijstelbloem@uva.nl

1. Walters, W. Comp. Eur. Polit. http://dx.doi. org/10.1057/s41295-016-0083-5 (2016).

2. Broeders, D. \& Dijstelbloem, H. in Digitizing Identities: Doing Identity in a Networked World (eds Van der Ploeg, I. \& Pridmore, J.) 242-260 (Routledge, 2016).

3. Amoore, L. The Politics of Possibility: Risk and Uncertainty Beyond Probability (Duke University Press, 2013).

4. Hasian, M. Forensic Rhetorics and Satellite Surveillance: The Visualization of War Crimes and Human Rights Violations (Lexington Books, 2016).

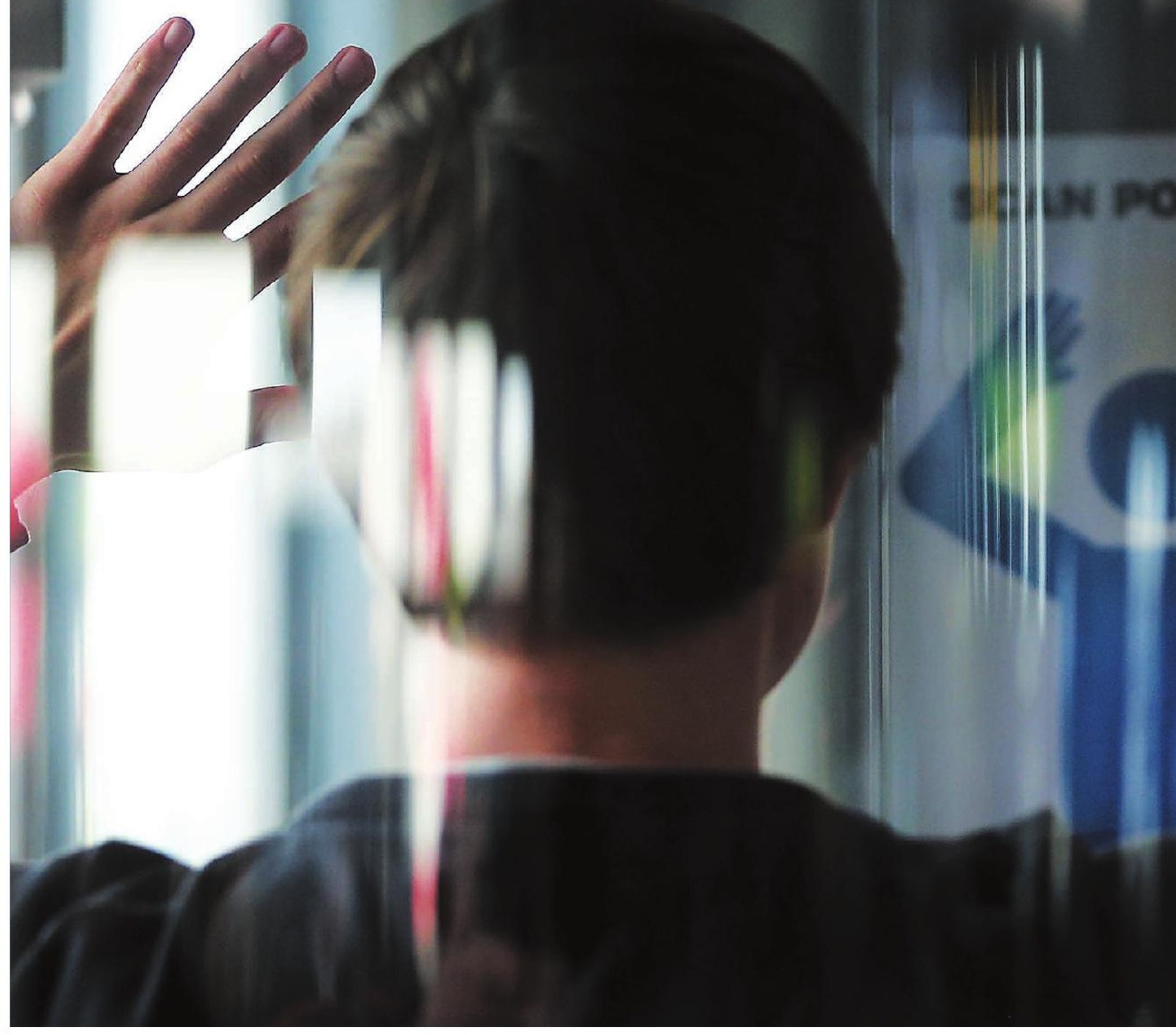

Body scanners are used at airport border crossings as an extra security-screening process.

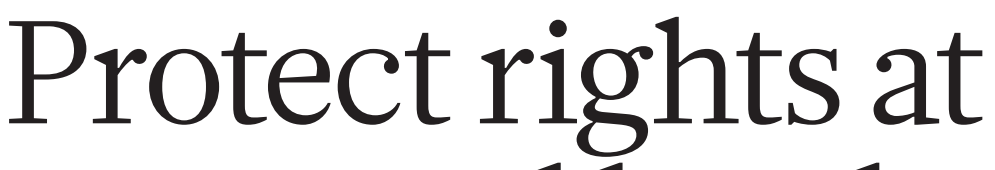
automated borders

\section{Gemma Galdon Clavell calls for checks and balances to avoid the indiscriminate sharing of personal data.}

\lceil n 2013, the European Union proposed expanding and harmonizing automated border crossings across the region. This Smart Borders initiative could soon be approved $^{1}$. The automated gates (e-gates) in place in many EU airports are the first phase. The European Agency for the Operational Management of Large-scale IT Systems in the Area of Freedom, Security and Justice (eu-LISA) is testing how to link them to databases and processes region-wide. Entries and exits will be stored in a database, replacing passport stamps. This information will be made available to border-control and immigration authorities, and will be linked to fingerprint records and watch lists held by police, customs and immigration agencies.

Around the world, such technologies are transforming the nature of regional and national borders in radical ways. Booths that recognize people's irises, faces and fingerprints are proliferating at airports, ports and other checkpoints. E-gates that compare identities against biometric records stored on chips in passports are supposedly faster, cheaper and more reliable than human border guards, and are presented as technical add-ons to the existing system. But, unmanaged, such technologies can threaten human rights and open up new forms of discrimination.

When our personal data are collected and shared before we board an aeroplane, a border ceases to be a line that separates countries or administrative areas. It becomes a process of monitoring, control and automated decisions. The physical border is increasingly irrelevant because our rights, privileges, relations, characteristics and risk levels are checked all the time.

When booking a ticket with an airline or agent, travellers enter biographical and 